\title{
Public procurement, innovation and industrial policy: rationales, roles, capabilities and implementation
}

DOI:

10.1016/j.respol.2019.103844

\section{Document Version}

Accepted author manuscript

Link to publication record in Manchester Research Explorer

\section{Citation for published version (APA):}

Uyarra, E., Zabala-Iturriagagoitia, J. M., Flanagan, K., \& Magro, E. (2020). Public procurement, innovation and industrial policy: rationales, roles, capabilities and implementation. Research Policy.

https://doi.org/10.1016/j.respol.2019.103844

\section{Published in:}

Research Policy

\section{Citing this paper}

Please note that where the full-text provided on Manchester Research Explorer is the Author Accepted Manuscript or Proof version this may differ from the final Published version. If citing, it is advised that you check and use the publisher's definitive version.

\section{General rights}

Copyright and moral rights for the publications made accessible in the Research Explorer are retained by the authors and/or other copyright owners and it is a condition of accessing publications that users recognise and abide by the legal requirements associated with these rights.

\section{Takedown policy}

If you believe that this document breaches copyright please refer to the University of Manchester's Takedown Procedures [http://man.ac.uk/04Y6Bo] or contact uml.scholarlycommunications@manchester.ac.uk providing relevant details, so we can investigate your claim.

\section{OPEN ACCESS}




\section{Public procurement, innovation and industrial policy: rationales, roles, capabilities and implementation}

Forthcoming in Research Policy Volume 49, Issue 1 (2020)

https://doi.org/10.1016/i.respol.2019.103844

Elvira Uyarraa, ${ }^{\mathrm{a},}$, Jon Mikel Zabala-Iturriagagoitia ${ }^{*}$, Kieron Flanagan $^{\mathrm{a}}$, Edurne Magro ${ }^{\mathrm{d}}$

a.- Manchester Institute of Innovation Research, Alliance Manchester Business School, University of Manchester, Manchester (United Kingdom)

b.- Western Norway University of Applied Sciences, Bergen (Norway)

c.- Deusto Business School, University of Deusto, Donostia-San Sebastian (Spain)

d.- Orkestra-Basque Institute of Competitiveness, University of Deusto, Donostia-San Sebastian (Spain)

*Corresponding author: imzabala@deusto.es

\section{Abstract}

Recent thinking about innovation and industrial policy emphasises purposeful related diversification strategies or more transformative - but potentially riskier - challenge-oriented policies. Meanwhile public procurement is increasingly seen as a key means of fostering innovation. We conceptualize the multiple roles of public procurement in an innovation policy landscape shaped by these emerging rationales, and explore the complexities and institutional work associated with its implementation. We identify some possible roles for government in fostering diversification and transformation through public procurement and explore the implementation challenges of institutionalising public procurement as part of innovation policy. Both the multiple potential roles of public procurement and the institutional work associated with its implementation are illustrated with the case of Galicia, Spain.

Keywords: Innovation-oriented public procurement; Institutional work; Institutional Entrepreneurship; Industrial policy; Smart Specialisation; Implementation.

JEL codes: $\mathrm{H} 57, \mathrm{O} 25, \mathrm{O} 38$. 


\section{1.- Introduction}

Innovation policy thinking has recently shifted towards more selective forms of intervention, whilst rationales have expanded to incorporate societal challenges. Addressing 'wicked problems' like poverty, ageing and climate change, rather than producing more innovations per se, is a core rationale for so called 'transformative innovation policies' (Schot and Steinmuller, 2018). At the same time there is much emphasis on diversification and technological upgrading - for instance the European Commission's agenda for Research and Innovation Strategies for Smart Specialisation (RIS3) aims to help regions to diversify and transform their economies based on their own competences and assets (Foray, 2014).

In this context scholars have pointed to demand-side policies, and in particular public procurement, as a means both of addressing societal challenges and enabling structural change. Innovation-oriented public procurement (PPI) was one of the tools included in the notional portfolio of policy instruments identified as relevant to the implementation of smart specialisation strategies in the first RIS3 Guide (European Commission, 2012). But adopting new instruments places substantial demands on public sector capabilities and practitioners 'on the ground' and, despite optimism about the transformative potential of PPI, uptake remains low, hampered by lack of technical capabilities of procuring organisations, poor coordination and inadequate incentive structures, amongst other barriers.

This paper addresses two literature gaps. First, despite recent interest in PPI, how it might contribute to regional innovation and diversification is underexplored. The PPI literature has dealt extensively with definitional issues relating to rationales, means and processes (Edler and Georghiou, 2007; Hommen and Rolfstam, 2009; Uyarra and Flanagan, 2010; Georghiou et al., 2014; Edquist and Zabala-Iturriagagoitia, 2015; Obwegeser and Müller, 2018). It has also provided empirical cases of procurement-driven innovations (Edquist et al., 2000, 2015), and explored the link between public procurement and innovation outcomes (Aschhoff and Sofka, 2009; Guerzoni and Raiteri, 2015; Georghiou et al., 2014; Raiteri, 2018). However, there remains no clear understanding of the role of procurement in relation to new innovation policy thinking, especially at the regional (subnational) level. What is distinctive about public procurement as a means of supporting (regional) innovation-based diversification and transformation?

The second literature gap relates to implementation: public procurement is a complex and interpretively flexible policy 'instrument' (see Flanagan et al., 2011), the implementation of which requires significant capabilities and institutional change (Rolfstam, 2013; Lember et al, 2015). Despite much interest in the barriers and challenges around the use of PPI (Uyarra et al., 2014), little attention has been paid to the institutionalisation and mainstreaming of this policy innovation. There are many cases of procurement induced innovations but we lack 'policy histories' of the institutionalisation of PPI as a policy approach. What activities and practices enable the implementation and institutionalisation of PPI?

In this paper we conceptualize the multiple roles of public procurement in (regional) innovation policy, and explore the complexities and institutional work associated with its implementation, using the empirical case of Galicia in Spain. A peripheral region, Galicia has pioneered the use of PPI as a means to nurture innovation and entrepreneurship, and more recently the articulation of regional diversification and transformation initiatives (Sánchez-Carreira et al., 2019). 
Our aim is three-fold. First, to link recent debates about challenge-oriented innovation policy with new industrial policy thinking. Second, to explore the multiple roles that procurement might play in economic development and structural change. Third, to understand the institutional and governance challenges associated with the use of PPI.

The paper is structured as follows. Section 2 discusses rationales, processes and challenges associated with new innovation policy ideas around transformation and diversification. Section 3 explores rationales for the use of PPI and evidences how this policy instrument can be related to (regional) diversification and transformation processes. Section 4 introduces the Galician context and presents our methodology. Section 5 presents the case of Galicia. Section 6 provides a discussion of the contribution of the paper while suggesting potential areas for further research. Finally, Section 7 draws conclusions.

\section{2.- Innovation policy for transformative change}

\section{1.- New framing of innovation policy}

Societal challenges are increasingly seen as legitimate drivers for innovation policy (Schot and Steinmuller, 2018; Mazzucato, 2015, 2018; Weber and Rohracher, 2012). Earlier systemic and market failure rationales (Smits and Kuhlmann, 2004) are felt to pay too little attention to the direction of innovation, rendering them unlikely to help address so-called 'wicked' problems such as poverty, climate change, etc. (Weber and Rohracher, 2012; Coenen et al., 2015; Frenken, 2017). Weber and Rohracher (2012) argue policies should instead be directed at addressing so-called 'transformative system failures' such as lack of directionality, limited reflexivity, poor coordination across policy domains and levels, and insufficient demand articulation. The latter is particularly important because there are many 'missing markets' related to these challenges (e.g., climate change, air quality, smart mobility, etc.) (ibid). Demand articulation, for instance through public procurement, increases the chances of innovation being accepted and adopted, shaping and legitimating the innovation process (Frenken, 2017; Grillitsch et al., 2019).

Meanwhile, Mazzucato (2015) has forcefully argued that policymakers have much to learn from the kind of 'mission-oriented' feats that led to putting a human being on the moon. Achieving such missions requires a confident 'entrepreneurial state' able to take risks and 'think big'. Yet most societal challenges are very different from such 'stretch' technological goals (Nelson, 1977). Apollo was an extraordinary technical feat but such missions have relatively clear objectives and can readily be mapped onto technological goals, however ambitious. Most societal problems are fuzzy and ill-defined, and therefore more likely to face strong problems of contestation and legitimacy (Boon and Edler, 2018; Kuhlmann and Rip, 2018; Schot and Steinmueller 2018). Tackling these problems requires a humbler, more experimental and less technocratic approach to policy that recognizes that "certain problems are poorly understood, and that it will not be easy to find solutions that will really solve anything" (Nelson, 1977, p.154).

Wicked problems, characterised by uncertainty and ambiguity about the nature and urgency of the problem, thus present key policy - and political - challenges around problem identification and definition. What is 'socially desirable' is not given but subject to interpretation (Fitjar et al., 2019), and will be differently felt, understood and acted upon in different places and at different spatial scales (Wanzenböck and Frenken, 2018). According to Frenken (2017, 
p.44), a moonshot approach will be appropriate only in rare cases - solving societal problems needs to start "from those parts of society where the challenge is actually present and partial knowledge about it is available". Actors implementing policies 'on the ground' are also more likely to possess the skills and practical knowledge necessary to understand place-specific problems and the context in which their solution will have to be implemented (Ansell et al., 2017; Flanagan and Uyarra, 2016).

\section{2.- New industrial policy, smart specialisation and related diversification}

All this suggests a need for a more bottom-up or place-sensitive approach to innovation policy, something generally lacking in the challenge-oriented innovation policy agenda (Coenen et al., 2015). From a different starting point, new approaches to industrial policy (Rodrik, 2004) such as 'smart specialisation' (Foray, 2014), and recent work by evolutionary economic geographers (for a review see Boschma, 2017) stress the importance of structural factors in shaping the extent to which national or regional economies can grow and diversify ${ }^{1}$. These approaches understand economic transformation as diversification of industrial structure and underlying capabilities (Janssen, 2019). Diversification is seen as a branching process, mainly driven by movement by firms into adjacent areas of specialisation ('related variety'). Unrelated diversification occurs less frequently, yet is more likely to help countries and regions move into technologically more advanced industries (Castaldi et al., 2015). These branching processes can lead to path extension, path renewal or, sometimes, new path creation (Grillitsch et al., 2018).

In this view, innovation policies should selectively build on unique place-specific characteristics and assets (McCann and Ortega-Argilés, 2013). Interventions should address specific 'coordination failures' that entrepreneurs face when exploring new opportunity spaces (Rodrik, 2004). Opportunities for diversification should be 'discovered' through a territoriallyrooted, contextualised process involving both public and private actors, rather than being dictated top-down. This is a reaction against, first, the tendency of policy-makers everywhere to pursue the same fashionable sectors, and second, the tendency for generic innovation policies to reinforce existing strengths rather than to broaden the range of innovation opportunities (Frenken, 2017).

While the literature on mission-oriented innovation policy has adopted an undifferentiated and technocratic understanding of missions, the literature on new industrial policy and smart specialisation typically lacks a normative stance entirely. Rather than seeking innovation that responds to societal aims or enhances public value (Tödtling and Trippl, 2018; Fitjar et al., 2019, Uyarra et al., 2019), the new industrial policy and smart specialisation literature seeks innovation purely to build future competitive advantage (Foray, 2018). The focus is on the entrepreneurial discovery process rather than policy outcomes, which are considered unknowable ex-ante (Radosevic, 2017). Yet according to Janssen and Frenken (2019, p.206) tackling societal challenges may support the emergence of new unrelated industries since it may expose firms "to knowledge from domains they would otherwise never look at", and give policy interventions additional legitimacy. Mazzucato (2018) argues the focus on entrepreneurial discovery processes is, essentially, a market failure rationale. For Andreoni

\footnotetext{
${ }^{1}$ While there is a renewed interest in industrial policy, this debate is not new, and draws from theoretical contributions made along several decades of industrial policy theory and practice, including structuralist development ideas of Pasinetti (1983) and others (for a recent review see Andreoni and Chang, 2019).
} 
and Chan (2019), industrial policy approaches neglect more fundamental 'structural coordination failures' shaping industrial transformation process, including demand constraints.

The focus on firm-led (regional) branching and discovery processes has been at the expense of considering the role of institutions (MacKinnon et al., 2019), particularly the role of the state in deliberately influencing conditions for transformative change (Dawley, 2014). The importance of the public sector in shaping demand conditions for innovation and transformation is rarely acknowledged (although see e.g. Martin and Coenen, 2015; Gee and Uyarra, 2013) - despite public procurement having been one of the key determinants of the radical transformation of Silicon Valley. With some exceptions (Martin and Coenen, 2015; Gee and Uyarra, 2013), the literature is silent on the role of public demand as a driver of transformation, and public procurement is especially neglected in regional innovation policy thinking (Morgan, 2017).

A more proactive role for the state requires significant work by institutional entrepreneurs, understood as distributed and embedded actors able to deviate from existing structures and initiate change leading to the genesis of new institutions (Battilana et al., 2009; Garud and Karnøe, 2003). By engaging in 'projective agency' (Dorado, 2005), institutional entrepreneurs purposively connect the past with the future in the form of visions or expectations - attracting interest, guiding activities in a particular direction, aligning actors and innovation networks and building hard and soft infrastructures (Steen, 2016). Institutional entrepreneurship implies changing taken for granted rules and routines in response to institutional pressures (Xing et al., 2018). This requires considerable work - and skill - to build political networks, develop technical capabilities, and culturally frame new practices (Lawrence and Suddaby, 2006). In doing so they are not so much discovering but creating entrepreneurial opportunities through the setting up of temporary innovation systems that can advance societal objectives and structures to "diffuse contextualized solutions across territories and sectors" (Frenken, 2017, p.45).

\section{3.- The potential of innovation-oriented public procurement}

Innovation-oriented public procurement (PPI) promises a number of benefits. To the extent that something new is purchased, procurement could create a 'lead customer' or a 'lead market' for an innovative product/service/process (European Commission, 2007). Procurement contracts might also act as an incentive for developers of new technologies, not all of whom will necessarily receive support from traditional $R \& D$ funding subsidies. Procurement may 'legitimize' product standards, creating new markets or expanding existing ones, thereby easing adoption and diffusion. In other words, procurement can accelerate both technological development and adoption, potentially leading to change in the composition of the overall industrial landscape. It can influence the evolution of existing and yet-to-be-created markets, changing the structure of competition to make it more attractive and/or accessible for new entrants (Neij, 2001; Bleda and Chicot, 2019).

Most of the PPI literature focuses on the national level, paying little attention to the spatial dimensions of procurement (Uyarra et al., 2017; van Winden and Carvalho, 2019). This is surprising given the considerable share of public purchasing undertaken at subnational levels, the significant spatial footprint of public demand and its influence on local economies and labour markets - not to mention the nature of demand closer or more adapted to end user needs in relation to domains such as transport, education or personal services, and its 
potential role in addressing challenges of both local and (eventually) global relevance (Uyarra et al., 2017; Dale-Clough, 2015).

Policy-makers with specific problems/needs may thus act as lead users, making their regions laboratories for experimentation (Henderson and Morgan, 2001) where "problems and solutions are framed and where policy tensions may be negotiated and creatively resolved" (Uyarra et al, 2017, p.832). At the same they may be limited by small domestic public and private markets and administrative capacity constraints (Cepilovs, 2013). A key issue is thus how place-specific experiments can diffuse more widely. Recent literature on urban experimentation (Bulkeley et al., 2015, von Wirth et al., 2018) has explored different types of diffusion or scaling up processes, including embedding into local structures (e.g., institutional embedding), translation or replication in other spheres, institutional contexts or localities, and scaling (incorporating more domains and practices, actors and/or resources). We identify similar processes in the case of the diffusion of PPI in Galicia in Section 5.

\section{1.- Public procurement for innovation and transformative change. Key rationales.}

In a previous contribution we elaborated on rationales for using procurement as a placesensitive innovation policy tool (Uyarra et al., 2017). We provided a framework for how PPI can add value to place-based economic development considering the geography of problems and solutions. We explored scenarios with different challenges and trade-offs, depending on whether problems are specific to one location, or are linked to or relevant for, multiple places; and whether solutions to these problems are shaped by the quality of local knowledge assets or connected to both local and global knowledge. We argued that PPI may be particularly relevant in the case of a well-defined need, or where local strengths in the knowledge base exist that could be used to address local and potentially global solutions. Based on Rutten (2017), we introduced the idea of conversations as a shorthand for how public procurement can modulate the content and breath of interactions with users and suppliers in each scenario. Conversations shape the participation and content of early dialogues among key stakeholders in public procurement, processes that can be more or less 'anchored' to place (see also van Winden and Carvalho, 2019).

However, there remains a need to better understand the potential roles public procurement can play in driving economic restructuring, and the complexities associated with utilising this policy approach. These complexities stem from, on the one hand, the contested nature of demand and the uncertainty around innovative solutions and markets to solve them, and, on the other, the capacities that public actors need to mobilise in order to implement these strategies in practice.

Articulating demand requires an understanding of a problem or need, as well as defining the opportunity space for solutions, often in interaction with the market or end users (Boon and Edler, 2018). The more difficult, intractable or wicked the problem the more complex and challenging demand articulation is likely to become and the greater the need to mobilise networks, build consensus and seek normative alignment around a particular problem. Solutions to these problems may also be contested and uncertain, for instance in terms of the feasibility of a technological solution and the complexity of its implementation.

Drawing from the literature on 'wicked problems', including Hoppe's (2011) differentiation between structured, unstructured and moderately structured problems, Wanzenböck et al. 
$(2019$, p.3) call for more attention to the heterogeneity of "underlying problem structures" and the "specific design of missions needed to tackle them". They offer a framework to understand different problem-solution constellations, arguing that while there may be some agreement or a shared vision around the nature of a problem or challenge, the choice of solution may remain uncertain or contested. In this case we may have a relatively well understood and widely shared, but nonetheless wicked, problem looking for a solution. Conversely there may be a set of innovative solutions that are feasible or preferred, yet the nature of the problem may not be sufficiently understood, too broadly framed to guide the search for solutions or perceived to lack legitimacy. Finally a situation of 'disorientation' or 'alignment' may exist when both problems and solutions diverge or converge respectively (Wanzenböck et al., 2019). Depending on the specific problem-solution combination they propose a problem-led pathway, a solution-led pathway or a hybrid pathway. We can link this to our idea of place-based public procurement and articulate different scenarios for the use of public procurement in innovation policy for economic diversification and transformation.

First, with an existing, relatively well articulated or agreed upon societal problem for which there is no known or clearly identifiable solution in the market, exploration and experimentation with different types of solutions will be required and public procurement may be mobilised to search for and provide direction to innovative markets. The presence of demanding public actors with sophisticated demands and sufficient purchasing power means that the public sector can act as a lead user enabling the formation of embryonic markets with potential for further diffusion (Beise and Cleff, 2004).

The challenge here is translating the problem into concrete needs and communicating them to the market so as to incentivise the development of innovative solutions, for instance using performance (outcome) specifications. For Bleda and Chicot (2019) this requires 'deep coordination' activities, whereby public purchasers signal that potential users exist for a technology, believe in its viability and are willing to use it. This can bring opportunities for regional path renewal by boosting innovation and diversification. Early engagement with the market enables greater awareness by public authorities of expert knowledge available in the region and which could be engaged in the development of solutions, via for instance market consultation or through more formalised means such as competitive dialogue (Uyarra et al., 2017). Unbundling strategies (dividing up procurement requirements in order to attract several small providers) or encouraging the building of consortia of firms would also increase participation of the local knowledge base (Timmermans and Zabala-Iturriagagoitia, 2013). Opportunities may also be sought by involving local development actors and organisations such as chambers of commerce and cluster organisations to build up the capacity of local businesses and raise awareness of future opportunities, and by aligning funding conditions for innovation support on the supply-side.

A second scenario, akin to the solution-led pathway proposed by Wanzenböck et al. (2019), sees procurement used to catalyse the development of particular technologies or markets identified as priorities. This can create "sophisticated and challenging demand on local sectors and markets that are considered important" for a national (or regional) economy (Lember et al., 2014, p.23).

Demand for these solutions may not be clearly understood, may be disputed, too broadly framed or responsibility may be too fragmented (Wanzenböck et al., 2019). Actors must be 
mobilised to align visions and interests across multiple stakeholders and governance levels, articulate demand and signal it effectively to the market (Uyarra and Flanagan, 2010). This can be done by aggregating or bundling demand (by identifying common or similar current or future requirements within a territory and with other regions (OGC, 2006). This is catalytic procurement, whereby the buying organisation acts "to catalyse the development of innovations for broader public use" rather than directly supporting its own aims (Edquist and Zabala-Iturriagagoitia, 2012, p.1759). Deep coordination (Bleda and Chicot, 2019) here involves not just creating demand but potentially making relevant regulatory and institutional changes to shift the selection environment to make it more favourable for the emergence of the innovation.

The need for deep coordination will be stronger the more complex the solution and the less related it is to existing economic specialisations. This poses greater challenges in terms of knowledge exchange amongst cognitively (and often geographically) distant actors, but also greater potential for path creation (Balland et al., 2018). Efforts may be needed to attract and 'anchor' external knowledge by linking it to local assets through, for instance up-skilling, subcontracting and development of proximity-based complementary activities (Uyarra et al., 2017).

In the third scenario, there may be a clear understanding of, and consensus about, both technological priorities/possibilities and societal problems (Wanzenböck et al., 2019). In this instance procurement can play a brokering role connecting identified economic strengths with global demand (Wang, 2015). This strategy could be seen as a component of a diffusionoriented innovation policy and may require only surface or operational coordination (Bleda and Chicot, 2019). The goal here is not necessarily to create brand new industries but rather to focus on the acquisition, diffusion and assimilation of existing innovations (Chiang, 1991). This kind of path extension usually takes place through incremental product and process innovations in existing sectors and along established technological paths (Moodysson et al., 2016). Public procurement here need not be innovation oriented but can still be 'innovation friendly' - i.e. practices and competencies that ensure that innovative solutions are not excluded or disadvantaged, mainstreamed into all public procurement practice (Knutsson and Thomasson, 2014; Uyarra and Flanagan, 2010).

A different strategy may be required in the fourth scenario, in which the product-solution constellation is characterised by profound uncertainty and contestation. The problem may be vague or contested, or its local relevance unclear, whilst solutions may be extremely uncertain or unrealistic given local technological and industrial capabilities. In this case procurement may be used as a tool to buy (i.e., support) industrial $R \& D$, to meet social demand and raise R\&D spending. This is pre-commercial procurement (PCP) rather than PPI (Lember et al., 2014). This may be a risky path to pursue, particularly if expectations about the promise of the technology to deliver both industrial diversification and address the identified challenge are not fulfilled. Pre-commercial procurement may also lack effectiveness if not linked to, or used in combination with, more commercial or solution-oriented public procurement (Edquist and Zabala-Iturriagagoitia, 2015).

Table 1.- Roles of PPI - a framework 


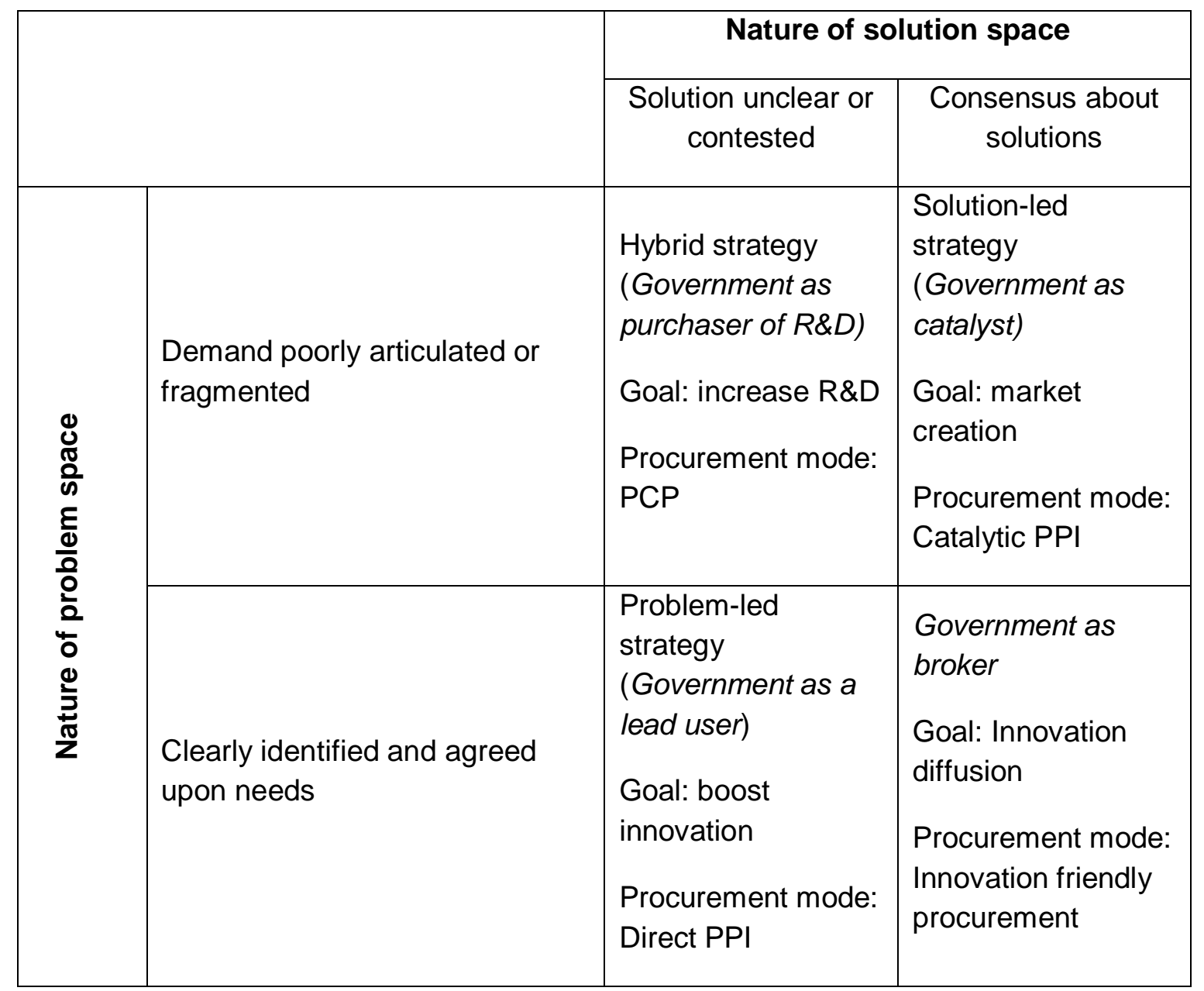

Source: Authors' own elaboration, building on Wanzenböck et al. (2019)

Table 1 illustrates the four problem/solution scenarios and the different strategies that could be followed to mobilise public procurement as a component of innovation policy for diversification and transformation. Roles and challenges are not mutually exclusive (they can be simultaneous or successive), and the degree of articulation should not be seen as an either/or dichotomy but as a continuum. Strategy would depend on the context (including institutional capacity), the prioritised domains, the scale of demand (i.e., from very specific regional/local demand to a broader international demand), and the timing of the intervention.

\section{2.- Rethinking implementation}

The above discussion demonstrates that making effective use of PPI is challenging, placing significant demands on governance and implementation in terms of the range of actors involved to effectively orchestrate demand and align priorities, the need for policy alignment between innovation and domain-specific policies to adequately embed and negotiate societal challenges, and multi-level coordination to ensure scaling up and diffusion of solutions. Significant institutional work will be necessary, not just to manage the specific procurement process but to embed it as instrument of innovation policy.

Barriers to PPI are well documented (see e.g., Uyarra et al., 2014), and include lack of procurement capabilities (including shortage of technical skills), risk aversion (and lack of political support), insufficient incentives, and regulatory challenges. Public procurement "is a complex market transaction with a high level of functional demands and risks involved that 
necessitates a broad range of capabilities" (Edler and Yeow, 2016, p.415). Public organisations are often overwhelmed by the demands associated with this practice, including the processes of defining needs, exploring solutions, conducting the procurement and adopting and using innovations.

New policy practices, particularly complex ones such as public procurement, are rarely adopted swiftly, wholesale and without conflict (Lawrence and Suddaby, 2006). Policies are subject to strong inertia and path-dependencies (Pierson, 2000). Adoption requires substantial institutional work on the part of institutional entrepreneurs "who must persuade others in their organizations of the merits of the innovation, experiment with the innovation in an effort to understand it and how it might apply to their own situations, modify it in order to gain internal legitimacy, and forge practical connections for the new structure or practice" (Lawrence and Suddaby, 2006, p.247).

Institutional work can be understood as the actions through which actors attempt to create, maintain, or disrupt institutional structures (Lawrence and Suddaby, 2006; Lawrence et al., 2009). This includes political work in which actors reconstruct rules, property rights and boundaries that define access to material resources through 'vesting', 'defining' and 'advocacy'. Actors engage in coalition building, bargaining and leveraging of resources, and work towards the enactment of new rules and regulations. A second set of practices are more cultural in nature, whereby institutional entrepreneurs seek to frame institutions to appeal to wider audiences and change discourses (Perkmann and Spicer, 2007). They include actions to 'construct identities', 'change norms' and 'construct networks' (Lawrence and Suddaby, 2006). The final category of actions, 'mimicry', 'theorizing' and 'educating', involves actions designed to alter abstract categorizations and meaning systems. These tactics are more technical in nature, seeking to shift mental models, educate in the new skills required, and actively work to embed, routinise or standardise practices to change the normative foundations of institutions.

This is important to the institutionalisation of PPI because of the inherent risks involved and lack of existing capabilities associated with the practice. Political work is needed to guarantee sufficient support to the policy, including strong senior buy-in, a clear delineation of roles and responsibilities, and mobilisation of resources to offset the cost and risk involved with the practice. Regulatory work is needed to define rules and procedures, and adaptation of existing practices in order to improve familiarity and ease adoption. Organisational changes are needed to support the management, monitoring and evaluation of the practice as well as creating intermediation structures to support links across the public sector (Edler and Yeow, 2016). Finally, PPI requires efforts to enable cultural change both in the supplier and public sector base, and work to improve the technical skills and training of procurers, and to create sufficient critical mass of trained professionals to institutionalise the practice.

\section{4.- Methodological approach and case context}

We adopt an argumentative turn (van Eeten, 2007). Arguments or narratives are treated as ordering devices for sense making in policy analysis (Fischer and Forester, 1993; Arrona and Zabala-Iturriagagoitia, 2019). We take a single case study approach, our case being the progressive institutionalisation of PPI as an element of regional innovation policy in Galicia over time. Case study research is appropriate for exploratory research in areas that require 
new conceptualization (Eisenhardt, 1989), and where 'when', 'how' or 'why' questions are being posed (Yin, 1984, p.13).

We combine the results of documentary analysis with a series of in-depth, semi-structured (face-to-face or telephone) interviews. Informants were actors who contributed to the development of PPI in Galicia; participants in policy design and implementation, and researchers who had either been involved in the definition, implementation, monitoring or evaluation of the innovation strategies or the procurement initiatives. We spoke to 14 informants in a series of semi-structured interviews of between $45 \mathrm{~min}$ and 1.5 hours between April 2018 and April 2019 (see Appendix). We interviewed some of our informants twice, to elicit deeper insights and to follow up points. We stopped seeking informants when further interviews ceased to provide additional new information.

The Spanish autonomous region of Galicia is located in the North West of the Iberian Peninsula, at the most western point of the EU. Galicia is a predominantly rural coastal region with a highly dispersed population of almost 3 million. After peak unemployment rates above $20 \%$ between 2012 and 2015, levels of unemployment are now around 12\% (December 2018). Galicia is rich in forest, marine and energy resources, and many of its socio-economic activities are related to traditional sectors such as fishing and marine activities. $24.6 \%$ of the population are older than 65 (December 2018), while the population under 15 has decreased from $23 \%$ in 1981 to $12 \%$ in 2018 . This creates challenges of rising health and social care costs and higher dependency ratios.

Although peripheral, Galicia not only pioneered the use of PPI in Spain but also institutionalised it as an instrument for innovation policy (Sánchez-Carreira et al., 2019). 40\% of the total investment in PPI in Spain was done in Galicia (€112M) between 2007 and 2014, and $€ 90 \mathrm{M}$ has so far been spent in this region in the 2014-2020 period. Galicia was also one of the first Spanish regions to introduce specific legislation to support PPI².

The Galician experience in PPI began in the health sector and later diffused across the Galician public sector. This case illustrates not only the roles PPI can play in innovation and economic development policy but also how PPI can become institutionalised. We show that the successful institutionalisation of PPI in Galicia has been the result of work by institutional entrepreneurs who over time built networks at various scales, mobilised resources, changed the regulatory environment, and upgraded the skill base.

\section{5.- The case of Galicia}

\section{9-2012: Adoption}

After the global financial crisis, Spain faced significant economic and political challenges. In its 2009 strategic plan, the Health Service of Galicia (SERGAS), serving 95\% of the Galician population and representing more than $40 \%$ of the regional government budget, indicated that the financial crisis would have direct consequences on its performance, and that innovation in new healthcare processes and new partnerships would be needed if the region was to respond

\footnotetext{
2 Support for PPI projects are embedded in the Galician Plan for Research, Innovation and Growth (Plan I2C); in the Law 5/2013, of promotion of research and innovation in Galicia; and in the Law $14 / 2013$, of rationalisation of the Galician public sector.
} 
to the needs of its ageing population. In effect SERGAS was forced to adopt a missionoriented regional innovation policy.

A new health innovation platform (a small multidisciplinary team) was tasked with coordinating innovation and research projects in healthcare, headed by a new director of Innovation and Management of Public Health. The director was a relative outsider, with no experience in public health but significant experience managing innovation projects in the private (engineering) sector. This may have made him more open to envision alternative policy solutions and different organisational arrangements.

Crucially, he was able to unlock funding at multiple levels. At the time, a significant share of the funding available to Galicia under the European Technology Fund 2007-2013 ${ }^{3}$ remained underspent, partly due to difficulties meeting the co-financing requirements. Meanwhile the Spanish Ministry of Science and Innovation was promoting the European Commission agenda around the use of PPI, with the sub-director of innovation for the Ministry a keen advocate. Together, the Ministry and SERGAS came to realise that the public-private nature of PPI, with its ultimate goal of boosting innovation in firms, fitted well both with the objectives of the Technology Fund and the objective of supporting open innovation in healthcare.

Access to funding required additional efforts to mobilise political and regulatory support at the regional level (e.g., to secure co-financing and overcome resistance) as well as to coordinate and align with national ministries and agencies such as the Centre for the Development of Industrial Technology (CDTI) ${ }^{4}$. Strong political buy-in to the idea of health innovation in Galicia, the strategic importance of SERGAS and a good understanding of the needs and challenges of the Galician health sector also facilitated this.

Galicia eventually defined two large PPI projects in health, InnovaSaúde and Hospital 2050, with a total budget of about $90 \mathrm{M} €$, both launched in 2011. These projects aimed to respond to the global challenge of elderly care and health by strengthening local and regional supply in order to target needs associated with international markets.

"We do not want to buy a specific solution for our needs, we want to buy a solution for needs that are common to us and others [...] so they [the firms] can address the same needs we have in other international markets" (Healthcare IT and Digital Health Program Manager at the Galician Health Service).

The process started with requests to potential suppliers, seeking innovative ideas to: 1) promote a safer, more efficient, intelligent and patient-centred health system, 2) improve intrahospital processes, and 3) offer new services to enable the development of the hospital of the future. This market consultation was followed by a process of analysis and reformulation of specifications for the procurement of innovative solutions. Prior to this an early-demand

\footnotetext{
${ }^{3}$ Multi-regional Operational Programme 2007-2013: Research, Development and Innovation for and by Enterprises - Technology Fund-under the Convergence and Regional Competitiveness and Employment Objectives, co-funded by the European Regional Development Fund (ERDF).

${ }^{4}$ The CDTI is a public entity whose mission is to foster technological development and innovation in Spain. Multi-level coordination was sought with the CDTI to better synchronize their financing to boost these bids.
} 
mapping was undertaken to signal needs to the market and allow sufficient time for firms to prepare (sometimes joint) proposals.

The scale and ambition of these projects presented significant technical and regulatory difficulties, however, and SERGAS lacked experience and capacity to implement PPI, for instance in relation to market consultation and complex tender specifications.

"We saw PPI as a flexible process, as a process of co-creation between firms and the public (government and society). We thought that PPI could have a great potential for us on the public side, and particularly for SERGAS. However, we were not aware of the extent to which this process requires professional and experienced staff' (Director general at the Galician Innovation Agency).

Overcoming these difficulties required significant efforts to mobilise existing expertise and support from across the regional government and particularly the legal directorate, and to train teams of people in the legal and technical aspects of public procurement. In organisational terms, it also required the establishment of more formal structures to manage the projects. The innovation platform was replaced by a Health Knowledge Agency (ACIS), set up to support the Galician health knowledge and innovation ecosystem. This helped institutionalise and consolidate PPI as a practice to support innovation in healthcare, including creating dedicated teams to respond to funding opportunities and manage procurement processes. This paved the way for further health projects.

"In the early stages the government acted as an entrepreneur, since it decided to engage in a policy instrument that nobody had even considered in Spain at the time, and therefore we were doing something pioneering. As a consequence of this type of initial role, we managed to generate an innovative ecosystem around health, where the SERGAS was the central body. The government was able to leverage the generation of such ecosystem, so other procurement contracts could emerge in parallel in other RIS priorities, as a consequence of this initial SERGAS experience" (Director of the innovation programs area at the Galician Innovation Agency).

The early initiatives had a strong demonstration effect for both public and private sectors. Around 300 people worked in the projects in some capacity and more than 100 firms responded to the call for proposals. A large proportion of contracts were eventually awarded to SMEs, often in collaboration with large firms, and Galician firms were involved in more than half of the contracts. Many subsequently won similar contracts with other regional administrations.

The perceived success led to other public organisations (e.g., universities, local authorities) becoming interested in PPI. The health innovation director of SERGAS became an informal mentor to other organisations seeking national government funding to attempt PPI. New informal networks emerged to explore the use of PPI, becoming more formal over time. An important link was with the new Agency for Technological Modernisation of Galicia (AMTEGA), created in 2011 with a budget in excess of $€ 100 \mathrm{M}$ to develop ICT-enabled tools to improve performance and service delivery in public administration. The assumptions held around PPI started to shift and its use started to diffuse to other regional stakeholders. 
Following the embedding of PPI in health and its diffusion to other aspects of public administration, it became a strategic innovation and industrial policy tool for the RIS3, orchestrated by the new Galician Innovation Agency (GAIN). GAIN was set up in 2012 with a budget of around $€ 90 \mathrm{M}$, a staff of circa 100 people and a remit to support the growth and competitiveness of Galician industry. It assumed responsibility for implementing programmes for research, technology and innovation previously held by the regional government's innovation directorate. It was also in charge of the RIS3, which was structured along three core priorities: (i) the management of natural and cultural resources; (ii) the future industrial model of Galicia; and (iii) a new healthy lifestyle model based on active ageing.

Soon after the creation of GAIN, the health innovation director of SERGAS was appointed as its new director. This coincided with the appointment of a new regional minister for industry and economic affairs who had previously been involved in negotiations for SERGAS PPI projects as a government advisor. This provided a favourable context to restructure and finetune the portfolio of innovation policy instruments, an 'opportunity to start from scratch', as one interviewee put it. This window of opportunity was seized to undertake a bold rationalisation of the instrument mix, simplifying the offer and introducing new tools such as accelerators, risk capital and PPI. Given the experience of both actors with Hospital2050 and InnovaSaúde, PPI was an obvious choice to pursue the objectives of the Galician RIS3.

At national level, ERDF funding for regional PPI projects had also transitioned into a more structured arrangement. During the period 2014-2020 the pluri-regional operative framework for smart growth had a specific line for demand-side innovation support measures and PPI ("Línea FID"). This was managed by the Ministry and interested public bodies had to apply for funding. After a protracted negotiation with the central government GAIN achieved a substantial increase in the budget allocation for PPI in Galicia vis a vis other instruments by persuading the government that there was both sufficient demand for this instrument across the Galician public sector and sufficient institutional capacity to manage it.

GAIN also lobbied the national government to become a one-stop shop for all PPI related enquiries in Galicia, arguing that they were already playing this role in practice, advising, supporting and training potential applicants for central government funding and weeding out weaker ideas before the formal proposal stage. GAIN thus became a trusted intermediary tasked with channelling all Galician bids for national PPI funding.

Most parts of the regional government had little experience of PPI and were resistant to adopt it. To overcome this, the new director kick-started a round of discussions with all government departments to convince them of the benefits of using PPI to support innovation and improve public services.

"One of the purposes we sought from GAIN was to inoculate the 'PPI virus' within the Xunta [the regional government], as well as within the rest of the consellerias [regional government departments] ... This is not a simple goal though, since not all consellerias are willing to assume the costs and risks derived from PPI. Normally public administrations do not have the means (financial, technological, knowledge-related capabilities) or the people (relational capabilities) to assume these risks (e.g., risks in legal advice, in coordination, in the source of funds, their use and justification)" (Former director of GAIN). 
The informal networks forged in the context of the early SERGAS initiatives crystallised into a cross-governmental working group to support the implementation of PPI, comprising AMTEGA, GAIN, the legal department of the regional government, the treasury department and SERGAS. The role of GAIN as orchestrator was formalised with a series of legal and procedural changes, including regulation to further articulate the use of PPI and make explicit the requirement that PPI needed to be channelled through GAIN ${ }^{5}$ and production of a 'how to' guide for practitioners drawing on the national one, but more hands-on and illustrated with local experiences ${ }^{6}$.

As GAIN grew in size and adopted a more formal structure with clearly defined competences, a small, dedicated team was created to manage PPI within the agency. Bidding for projects also became formalised into a region-wide call for proposals that would be first evaluated by GAIN before being approved by the ministry. To encourage participation and ensure financial viability, GAIN would offer half of the regional co-financing required by the national PPI scheme.

Proposals had to demonstrate alignment with RIS3 priority areas, impact on public services and potential for technological upgrading of regional firms. They also needed to include a plan for long term development and adoption, which required strong high-level buy-in in the relevant government departments. The regional call was accompanied by efforts by GAIN to further raise awareness of PPI, and by training sessions for public officials to build capacity to bid for and manage PPI processes. It was realised that "for PPI to become institutionalized in other areas beyond health, we need to train both the public administration (governments, agencies and the user) and the firms" (Healthcare IT and Digital Health Program Manager at the Galician Health Service). The call not only led to the expression of public sector needs but also the identification of common needs and potential synergies across the administration.

The first call generated 30 proposals, around half of which were submitted to the national ministry, and four of which were eventually funded. The largest were a SERGAS project around healthy aging (Código100) and a GAIN project to develop technological solutions based on UAVs (Unmanned Aerial Vehicles). The objective of the latter was to promote the use of civil UAVs to improve public services through public-private partnerships with strategic technological and industrial partners. The aim was to diversify the regional economy based on existing manufacturing strengths by identifying new technology niches in the nascent UAV industry, anchoring new knowledge and activities via demand pull policy instruments. With a budget of $€ 149 \mathrm{M}$ ( $50 \%$ co-financed by the private sector), this project was far more ambitious and complex than the PPI actions previously undertaken by SERGAS, evidencing a shift towards the more strategic use of PPI as an innovation policy instrument.

This UAV initiative followed a similar structure to previous projects, with early market consultations (including a large diffusion campaign to attract the interest of the global aerospace industry) to prepare the calls and inform potential beneficiaries about the goals targeted and specific requirements, and an early demand mapping to signal demand needs. ${ }^{7}$

\footnotetext{
${ }^{5}$ Ley $5 / 2013$, de 30 de mayo, de fomento de la investigación y de la innovación de Galicia. See: https://www.xunta.gal/dog/Publicados/2013/20130617/AnuncioC3B0-060613-0002 es.html

${ }^{6}$ See: http://documentos.galiciainnovacion.es/CUI/Guia completa cast.pdf

${ }^{7}$ This early market demand can be found here (in Spanish): http://documentos.galiciainnovacion.es/CUI/Mapa Demanda Tempera GL ES EN.pdf
} 
This was done in two phases, one aimed at pre-commercial development of R\&D based technological solutions (i.e. PCP), and a second one aimed at purchasing specific UAV solutions.

Whereas in the SERGAS case the demand was clearly articulated and uncontroversial, in the case of the civil UAV initiative, the definition of demand was more complex. It was thought that Galicia could be a testing ground for the development of technological solutions for sustainable land management (e.g., forest fire prevention, control of forest and agricultural pests, territorial planning), coastal security and other off-shore applications such as fishery surveillance, airspace-related applications such as interoperability between manned and unmanned aircraft, and other challenges being faced not only in Galicia but also in other places.

Defining these complex challenges required extensive cross-departmental consultation and dialogue before being put to the market. The informal networks built by GAIN and the demonstration effect of previous experiences helped, enabling the management of the project between GAIN and six government departments.

The UAV initiative can be regarded as catalytic procurement in the Galician RIS3, being based on a horizontal technology that could help diversify many relevant economic sectors of the Galician economy into a new activity with the potential to attract foreign direct investment to the region and link the local supply base with multinational firms. This required additional policy interventions to support infrastructure development and high technology equipment, training activities, regulatory change and efforts to help diversify Galician traditional manufacturing and engineering firms into the nascent UAV sector.

\section{From 2016 onwards: Consolidation}

In this period internal capacity to manage PPI policy was further strengthened, with a doubling of dedicated staff. Support and training for the use of PPI was further professionalised and formalised and a professionally accredited specialist course was developed between GAIN and the Galician School for Public Administration (EGAP). In addition, the internal call for PPI projects was replicated in 2017 and became a standard practice to incentivise the use of PPI.

These processes were formalised under a new programme aimed at strengthening the implementation of PPI, and complemented by awareness building activities among public and private sectors, incentives for adoption (in the form of prizes for public sector innovators) and the creation of a formal Galician PPI network.

This enabled the further embedding and routinisation of PPI as a policy instrument, overcoming earlier resistance and capability shortages. The visibility of the UAV initiative, aided by numerous awards for its innovative nature, gave additional legitimacy to GAIN's efforts.

Galicia was now increasingly seen as a reference in the use of PPI, and GAIN was being asked to provide expertise and be part of informal policy learning networks at the EU level and beyond. Other regions followed the Galician example, with Galicia's institutional entrepreneurs often acting as consultants - further reinforcing and validating its use within the region. 
"In 2018 there have been 10 new tenders related to PPI, so the evolution of this instrument in Galicia is exponential. We observe that a qualitative leap is taking place, mainly because the pioneering project of the SERGAS (Innovasaúde and Hospital2050) which has served to generate more confidence in the instrument. The experience of SERGAS is also sending the signal to policy managers that Galicia has become a benchmark in innovation policy, although this was never a pursued objective" (Director of the innovation programs area at the Galician Innovation Agency).

While the arrangement with the national government to bid for ERDF-PPI projects remained, regional actors were increasingly using their own funds to do PPI. The combination of new procurement directives allowing a broader and more flexible range of procedures, including innovation partnerships, and the experience and expertise accumulated in managing PPI projects, gave them the confidence to undertake these activities without ERDF funds, further normalising and embedding the use of PPI in Galicia.

"It is clear for us there is no step back and that PPI is consolidated in Galicia, and we will continue using it even in the absence of the ERDF or support from the national level" (Director general at the Galician Innovation Agency).

\section{6.- Discussion}

The Galician experience illustrates our different scenarios for the use of PPI as an innovation policy tool. SERGAS first used PPI in healthcare, seeking innovative solutions to relatively well-defined needs. PPI was shaped to ensure that needs were communicated to the market early on and that demand was sufficiently broad to attract solutions relevant to both local and global needs but challenging enough to encourage innovation. PPI was subsequently used catalytically to shape the market for an emerging niche technology - UAVs. Demand for UAVenabled solutions was poorly understood and its articulation required 'deep coordination', not just with the private sector but also across government, at both operational and high levels. Additional interventions were devised to shape the selection environment influencing the market for UAV solutions, including investment in vocational training and infrastructure, regulatory change and entrepreneurship support in order to retain value in the region. The Galician government also used procurement as R\&D policy through the use of pre-commercial procurement (generally embedded in broader projects, typically preceding a call for commercial solutions). Finally, the use of PPI for adoption and diffusion can be seen in a general shift to innovation friendly procurement in tenders, and a consideration of long-term adoption of innovative solutions.

The introduction of PPI in Galicia was enabled by a number of distinctive factors, including severe economic pressures in the aftermath of the financial crisis, an emerging narrative in EU and national policy circles about PPI, a relatively favourable political environment which provided a window of political opportunity to experiment with new approaches, and availability of financial resources. Whilst some of these factors clearly gave an impulse to the initial adoption of PPI they do not necessarily explain the subsequent diffusion and embedding of the practice, which required deliberate actions by institutional entrepreneurs. Politically, significant efforts were needed to elicit the necessary support, including financial and regulatory support. This involved strong advocacy for the more 'open' approach to solving 
public sector problems which PPI represented. This was done at multiple levels, requiring negotiations and compromise with the national level which resulted in additional resources and a redefinition of responsibilities which gave GAIN a mandate to coordinate, support and monitor PPI in Galicia. It also involved work to reconstruct legal frameworks and boundaries that defined access to resources, and the definition of procedures and standards for the selection of projects to be supported.

Institutional entrepreneurs also sought to build dedicated teams and professional identities around PPI, first by mobilizing like-minded people and then lobbying for further training and recruiting of staff with particular profiles. These efforts created a strong identity among the actors involved in the early stages of institutionalization of PPI in Galicia, which one recalled as the 'highlight of their professional career'.

Culturally, normative associations started to shift as a result of consultation and dialogue across the public sector, and efforts to link the EU and national narrative around PPI to the Galician context (e.g. through 'how-to' guides to make it more relevant to regional practitioners). This helped build strong interorganizational networks across the public sector. Initial informal connections to exchange experiences became the foundation for more formal arrangements and helped build trust to undertake more complex projects, complemented by technical work to educate actors with the knowledge necessary to engage with PPI (including the development of dedicated professional qualifications, standardization of practices and streamlining of procedures).

Institutional work of a more cultural and political nature was particularly important at the early stages, whereas technical work to educate practitioners, clarify procedures and routinise practices was more important later. As the policy has consolidated, institutional work has shifted towards maintenance efforts to embed the practice and reinforce its normative foundations.

As a result of these efforts over the period of ten years, PPI practices were progressively embedded across the public sector and scaled up to involve more actors, more resources, and more complex policy interventions. The sequence of events is not trivial, as the more complex industrial policy interventions such as the UAV initiative were only possible after regional actors had gained political trust and legitimacy and could demonstrate initial results.

\section{7.- Conclusion}

There is growing interest in how innovation policy can be more selectively used to pursue transformative change. On the one hand, there is an argument that innovation policy should steer economic transformation in socially desirable directions. On the other hand, influenced by new industrial policy and evolutionary economic geography approaches, there is the idea that innovation policy should be more targeted and selective, pursuing priorities with stronger potential for economic diversification and structural change.

These distinct visions of innovation policy for transformative change often become conflated. But while new forms of transformative innovation policy adopt a top-down approach that takes a particular societal challenge as a starting point and seeks to modulate or steer existing sociotechnical systems in that direction, new industrial policy approaches adopt a bottom-up structural approach that takes existing regional strengths as a starting point and identifies 
particular areas of technological specialisation order to diversify the economic base. We believe that PPI can bring together and help articulate the problem and solution spaces highlighted by these two currently competing innovation policy agendas.

To do this, and reflecting the observation that both problems and solutions are (or could be) locally anchored, we offer a framework to understand the roles that PPI can play in regional policy. Through this we explore how territories can capture part of the 'value' they have helped to co-create (Bailey et al., 2018). This may be relevant not only in the context of RIS3, but more generally in the context of addressing grand societal challenges through missionoriented and transformative innovation policies. We aim to contribute to the discussion started by Pickernell et al. (2011) and Uyarra et al. (2017), amongst others, on the different geographies of public procurement and on path creation. Our proposed framework, illustrated through the case of Galicia, implies that PPI could be a means to achieve "creative construction" (see Lambooy, 2005) as well as to create - not just discover - entrepreneurial opportunities.

However, policies for transformative change place great demands on public sector capabilities, yet these are often weak, particularly in peripheral regions. Innovation policy discourses frequently make much of the potential for public procurement, but the many regulatory and institutional complexities of implementation are assumed away. Shifting from a predominantly supply-side logic of innovation policy to the use of PPI requires significant political, cultural and organizational changes. At the same time innovation policies are subject to strong inertia and path dependence. We show that the adoption and subsequent evolution of PPI in Galicia was a consequence of significant work by institutional entrepreneurs who seized opportunities to mobilise funding, lobbied for support at multiple levels of government (locally and nationally), and pushed to change normative associations and culture, as well as for changes in routines and procedures, including the legal framework. We believe policy histories such as the one we offer here can help us improve our understanding of the institutional processes through which policy innovations can be successfully implemented and become established (Flanagan et al, 2011; Flanagan and Uyarra, 2016).

\section{Acknowledgements}

Preliminary versions of this paper were presented at research seminars at the Copernicus Institute of Sustainable Development (Utrecht University), the Centro Ricerche Economiche Nord-Sud at the University of Cagliari, and at the International Conference on Public Policy (ICPP4) in Montreal. The authors are grateful for the comments received. Jon Mikel ZabalaIturriagagoitia and Edurne Magro acknowledge financial support from the Basque Government Department of Education, Language Policy and Culture (IT 885-16). Elvira Uyarra and Kieron Flanagan acknowledge research support from the Alliance Manchester Business School. The authors wish to acknowledge the comments of two anonymous reviewers, whose incisive critiques spurred us to focus in detail on the Galician case. 


\section{References}

Andreoni, A., Chang, H.J. 2019. The political economy of industrial policy: Structural interdependencies, policy alignment and conflict management. Structural Change and Economic Dynamics, 48, 136-150.

Ansell, C., Sørensen, E., Torfing, J. 2017. Improving policy implementation through collaborative policymaking. Policy \& Politics, 45(3), 467-486.

Arrona, A., Zabala-Iturriagagoitia, J.M. 2019. On the study and practice of regional innovation policy: the potential of interpretive policy analysis. Innovation: The European Journal of Social Science Research, 32(1), 148-163.

Aschhoff, B., Sofka, W. 2009. Innovation on demand-Can public procurement drive market success of innovations?. Research Policy, 38, 1235-1247.

Bailey, D., Pitelis, C., Tomlinson, P.R. 2018. A place-based developmental regional industrial strategy for sustainable capture of co-created value. Cambridge Journal of Economics, 42(6), $1521-1542$.

Balland, P.A., Boschma, R., Crespo, J., Rigby, D.L. 2018. Smart specialization policy in the European Union: relatedness, knowledge complexity and regional diversification. Regional Studies, in press.

Battilana, J., Leca, B., Boxenbaum, E. 2009. How actors change institutions: towards a theory of institutional entrepreneurship. Academy of Management Annals, 3(1), 65-107.

Beise, M., Cleff, T. 2004. Assessing the lead market potential of countries for innovation projects. Journal of International Management, 10, 453-477.

Fitjar, R., Benneworth, P., Asheim, P. 2019. Towards Regional Responsible Research and Innovation? Science and Public Policy, in press.

Bleda, M., Chicot, J. 2019. The role of public procurement in the formation of markets for innovation. Journal of Business Research, in press.

Boon, W., Edler, J. 2018. Demand, challenges, and innovation. Making sense of new trends in innovation policy. Science and Public Policy, 45(4), 435-447.

Boschma, R. 2017. Relatedness as driver of regional diversification: A research agenda. Regional Studies, 51(3), 351-364.

Bulkeley, H.A., Broto, V.C., Edwards, G.A. 2015. An urban politics of climate change: experimentation and the governing of socio-technical transitions. London, Routledge.

Castaldi, C., Frenken, K., Los, B. 2015. Related variety, unrelated variety and technological breakthroughs: an analysis of US state-level patenting. Regional Studies, 49(5), 767-781.

Cepilovs, A. 2013. Public procurement for innovation in small states. The case of Latvia. Rivista di Politica Economica, 2, 99-136. 
Chiang, J-T. 1991. From mission-oriented to diffusion-oriented paradigm: the new trend of US industrial technology policy. Technovation, 11(6), 339-356.

Coenen, L., Hansen, T., Rekers, J.V. 2015. Innovation policy for grand challenges. an economic geography perspective. Geography Compass, 9(9), 483-496.

Dale-Clough, L. 2015. Public procurement of innovation and local authority procurement: procurement modes and framework conditions in three European cities. Innovation: The European Journal of Social Science Research, 28(3), 220-242.

Dawley, S. 2014. Creating new paths? Offshore wind, policy activism, and peripheral region development. Economic Geography, 90(1), 91-112.

Dorado, S. 2005. Institutional entrepreneurship, partaking, and convening. Organization Studies, 26(3), 385-414.

Edler, J., Georghiou, L. 2007. Public procurement and innovation - Resurrecting the demand side. Research Policy, 36, 949-963.

Edler, J., Yeow, J. 2016. Connecting demand and supply: The role of intermediation in public procurement of innovation. Research Policy, 45(2), 414-426.

Edquist, C., Hommen, L., Tsipouri, L. (Eds), 2000. Public Technology Procurement and Innovation. Dordrecht, Kluwer Academic Publishers.

Edquist, C., Vonortas, N.S., Zabala-Iturriagagoitia, J.M., Edler, J. (Eds), 2015. Public Procurement for Innovation. Cheltenham, Edward Elgar.

Edquist, C., Zabala-Iturriagagoitia, J.M. 2012. Public Procurement for Innovation as missionoriented innovation policy. Research Policy, 41(10), 1757-1769.

Edquist, C., Zabala-Iturriagagoitia, J.M. 2015. Pre-Commercial Procurement: a demand or supply policy instrument in relation to innovation?. R\&D Management, 45(2), 147-160.

van Eeten, M.J.G. 2007. Narrative Policy Analysis. In, Fischer, F., Miller, G.J., Sidney, M.S. (Eds.) Handbook of Public Policy Analysis: Theory, Politics and Methods. CRC Press, Boca Ratón, pp. 251-272.

Eisenhardt, K.M. 1989. Building Theories from Case Study Research. Academy of Management Review, 14(4), 532-550.

European Commission, 2007. A lead market initiative for Europe. COM(2007) 860.

European Commission, 2012. Guide to Research and Innovation Strategies for Smart Specialisation (RIS 3). European Commission, Brussels.

Fischer, F., Forester, J. 1993. The Argumentative Turn in Policy Analysis and Planning. London, UCL Press.

Flanagan, K., Uyarra, E. 2016. Four dangers in innovation policy studies - and how to avoid them. Industry and Innovation, 23(2), 177-188. 
Flanagan, K., Uyarra, E., Laranja, M. 2011. Reconceptualising the 'policy mix' for innovation. Research Policy, 40(5), 702-713.

Foray, D. 2018. Smart specialization strategies as a case of mission-oriented policy-a case study on the emergence of new policy practices. Industrial and Corporate Change, 27(5), 817832.

Foray, D. 2014. Smart specialisation: Opportunities and challenges for regional innovation policy. London, Routledge.

Frenken, K. 2017. A complexity-theoretic perspective on innovation policy. Complexity, Innovation and Policy, 3(1), 35-47.

Fuenfschilling, L., Truffer, B. 2016. The interplay of institutions, actors and technologies in socio-technical systems-An analysis of transformations in the Australian urban water sector. Technological Forecasting and Social Change, 103, 298-312.

Garud, R., Karnøe, P., 2003. Bricolage versus breakthrough: distributed and embedded agency in technology entrepreneurship. Research policy, 32(2), 277-300.

Gee, S., Uyarra, E. 2013. A role for public procurement in system innovation: the transformation of the Greater Manchester (UK) waste system. Technology Analysis \& Strategic Management, 25(10), 1175-1188.

Georghiou, L., Edler, J., Uyarra, E., Yeow, J. 2014. Policy instruments for public procurement of innovation: Choice, design and assessment. Technological Forecasting \& Social Change, 86, 1-12.

Grillitsch, M., Asheim, B., Trippl, M. 2018. Unrelated knowledge combinations: the unexplored potential for regional industrial path development. Cambridge Journal of Regions, Economy and Society, 11, 257-274.

Grillitsch, M., Hansen, T., Coenen, L., Miörner, J. and Moodysson, J., 2019. Innovation policy for system-wide transformation: The case of strategic innovation programmes (SIPS) in Sweden. Research Policy, 48(4), 1048-1061.

Guerzoni, M., Raiteri, E., 2015. Demand-side vs. supply-side technology policies: Hidden treatment and new empirical evidence on the policy mix. Research Policy, 44(3), 726-747.

Henderson, D., Morgan, K. 2001. Regions as laboratories: The Rise of Regional Experimentalism in Europe. In, M.S. Gertler, D.A. Wolfe, D.A. (Eds.) Innovation and Social Learning: Institutional Adaptation in an Era of Technological Change. Basingstoke, MacMillan, pp. 204-226.

Hommen, L., Rolfstam, M. 2009. Public Procurement and Innovation: towards a taxonomy. Journal of Public Procurement, 9(1), 17-56.

Hoppe, R. 2011. The governance of problems: Puzzling, powering and participation. Bristol, Bristol University Press. 
Janssen, M.J. and Frenken, K., 2019. Cross-specialisation policy: rationales and options for linking unrelated industries. Cambridge Journal of Regions, Economy and Society, 12(2),195212.

Janssen, M.J. 2019. What Bangs for Your Buck? Assessing the Design and Impact of Dutch Transformative Policy. Technological Forecasting and Social Change, 138, 78-94.

Knuttsson, H., Thomasson, A. 2014. Innovation in the Public Procurement Process: A study of the creation of innovation-friendly public procurement. Public Management Review, 16(2), 242-255.

Kuhlmann, S., Rip, A., 2018. Next-generation innovation policy and grand challenges. Science and Public Policy, 45(4), 448-454.

Lambooy, J. 2005. Innovation and knowledge: Theory and regional policy. European Planning Studies, 13(8), 1137-1152.

Lawrence, T.B., Suddaby, R. 2006. Institutions and institutional work. In, S.R. Clegg, C. Hardy, T.B. Lawrence, W.R. Nord (Eds.) Sage Handbook of Organization Studies, 2nd Edition. London, Sage, pp. 215-254.

Lawrence, T.B., Suddaby, R., Leca, B. 2009. Institutional Work: Actors and Agency in Institutional Studies of Organizations. Cambridge, Cambridge University Press.

Lember, V., Kattel, R., Kalvet, T. 2014. Public Procurement, Innovation and Policy: International Perspectives. Heidelberg, Springer

Lember, V., Kattel, R., Kalvet, T. 2015. Quo vadis public procurement of innovation?. Innovation: The European Journal of Social Science Research, 28(3), 403-421.

Martin, H., Coenen, L. 2015. Institutional context and cluster emergence: The biogas industry in Southern Sweden. European Planning Studies, 23(10), 2009-2027.

MacKinnon, D., Dawley, S., Pike, A. and Cumbers, A., 2019. Rethinking path creation: A geographical political economy approach. Economic Geography, 95(2), 113-135.

Mazzucato, M. 2015. The entrepreneurial state: Debunking public vs. private sector myths (Vol. 1). London, Anthem Press.

Mazzucato, M. 2018. Mission-oriented innovation policies: challenges and opportunities. Industrial and Corporate Change, 27(5), 803-815.

McCann, P., Ortega-Argilés, R. 2013. Modern regional innovation policy. Cambridge Journal of Regions, Economy and Society, 6(2), 187-216.

Moodysson, J., Trippl, M., Zukauskaite, E. 2016. Policy learning and smart specialization: balancing policy change and continuity for new regional industrial paths. Science and Public Policy, 44(3), 382-391.

Morgan, K. 2017. Nurturing novelty: Regional innovation policy in the age of smart specialisation. Environment and Planning C: Government and Policy, 35(4), 569-583. 
Neij, L. 2001. Methods of evaluating market transformation programmes: experience in Sweden. Energy Policy, 29, 67-79.

Nelson, R.R. 1977. The moon and the ghetto. An essay on public policy analysis. New York, Norton.

Obwegeser, N., Müller, S.D. 2018. Innovation and public procurement: Terminology, concepts, and applications. Technovation, 74, 1-17.

OGC, 2006. Aggregation: Is bigger always better?. Office of Government Commerce, London.

Pasinetti, L.L. 1983. Structural change and economic growth: a theoretical essay on the dynamics of the wealth of nations. CUP Archive.

Perkmann, M., Spicer, A. 2007. Healing the scars of history': Projects, skills and field strategies in institutional entrepreneurship. Organization Studies, 28(7), 1101-1122.

Pickernell, D., Kay, A., Packham, G., Miller, C. 2011. Competing agendas in public procurement: an empirical analysis of opportunities and limits in the UK for SMEs. Environment and Planning C: Government and Policy, 29, 641-658.

Pierson, P. 2000. Increasing returns, path dependence, and the study of politics. American Political Science Review, 94(2), 251-267.

Radosevic, S. 2017. Assessing EU smart specialisation policy in a comparative perspective. In, S. Radosevic, A. Curaj, R. Gheorghiu, L. Andreescu, I. Wade (Eds.) Advances in the theory and practice of smart specialization. London, Academic Press, pp. 2-37.

Raiteri, E. 2018. A time to nourish? Evaluating the impact of public procurement on technological generality through patent data. Research Policy, 47(5), 936-952.

Rodrik, D. 2004. Industrial policy for the twenty-first century. KSG Working Paper No. RWP04047.

Rolfstam, M. 2013. Public procurement and innovation. Cheltenham, Edward Elgar Publishing.

Rutten, R. 2017. Beyond proximities: The socio-spatial dynamics of knowledge creation. Progress in Human Geography, 41(2), 159-177.

Sánchez-Carreira, M.C., Peñate-Valentín, M.C., Varela-Vázquez, P. 2019. Public procurement of innovation and regional development in peripheral areas. Innovation: The European Journal of Social Science Research, 32(1), 119-147.

Schot, J., Steinmueller, W.E. 2018. Three frames for innovation policy: R\&D, systems of innovation and transformative change. Research Policy, 47(9), 1554-1567.

Smits, R., Kuhlmann, S. 2004. The rise of systemic instruments in innovation policy. The International Journal of Foresight and Innovation Policy, 1, 4-32.

Steen, M. 2016. Reconsidering path creation in economic geography: aspects of agency, temporality and methods. European Planning Studies, 24(9), 1605-1622. 
Timmermans, B., Zabala-Iturriagagoitia, J.M. 2013. Coordinated unbundling: A way to stimulate entrepreneurship through public procurement for innovation. Science and Public Policy, 40(5), 674-685.

Tödtling, F., Trippl, M. 2018. Regional innovation policies for new path development-beyond neo-liberal and traditional systemic views. European Planning Studies, 26(9), 1779-1795.

Uyarra, E., Flanagan, K. 2010. Understanding the innovation impacts of public procurement. European Planning Studies, 18(1), 123-143.

Uyarra, E., Edler, J., Garcia-Estevez, J., Georghiou, L., Yeow, J. 2014. Barriers to innovation through public procurement: A supplier perspective. Technovation, 34(10), 631-645.

Uyarra, E., Flanagan, K., Magro, E., Zabala-Iturriagagoitia, J.M. 2017. Anchoring the innovation impacts of public procurement to place: The role of conversations. Environment and Planning C: Politics and Space, 35(5), 828-848.

Uyarra, E., Ribeiro, B., Dale-Clough, L. 2019 Exploring the normative turn in regional innovation policy: responsibility and the quest for public value. European Planning Studies, in press.

van Winden, W., Carvalho, L. 2019. Intermediation in public procurement of innovation: How Amsterdam's startup-in-residence programme connects startups to urban challenges. Research Policy, in press.

Wang, D. 2015. Activating cross-border brokerage interorganizational knowledge transfer through skilled return migration. Administrative Science Quarterly, 60(1), 133-176.

Wanzenböck, I., Frenken, K. 2018. The subsidiarity principle: Turning challenge-oriented innovation policy on its head (No. 1806). Utrecht University, Department of Human Geography and Spatial Planning, Group Economic Geography.

Wanzenböck, I., Wesseling, J., Frenken, K., Hekkert, M., Weber, M. 2019. A framework for mission-oriented innovation policy: Alternative pathways through the problem-solution space. SocArXiv. February 14. doi:10.31235/osf.io/njahp.

Weber, K.M., Rohracher, H. 2012. Legitimizing research, technology and innovation policies for transformative change. Combining insights from innovation systems and multi-level perspective in a comprehensive failures framework. Research Policy, 41, 1037-1047.

von Wirth, T., Fuenfschilling, L., Frantzeskaki, N., Coenen, L. 2019. Impacts of urban living labs on sustainability transitions: Mechanisms and strategies for systemic change through experimentation. European Planning Studies, 27(2), 229-257.

Xing, Y., Liu, Y., Cooper, S.C.L. 2018. Local Government as Institutional Entrepreneur: PublicPrivate Collaborative Partnerships in Fostering Regional Entrepreneurship. British Journal of Management, 29(4), 670-690.

Yin, R.K. 1984. Case study research: design and methods. Sage, Thousand Oaks, California. 


\section{Appendix}

Table A.1.- Profiles of the interviewed stakeholders

\begin{tabular}{|c|c|c|}
\hline Interviewee & Affiliation & Role \\
\hline 1 & $\begin{array}{l}\text { University of Santiago de } \\
\text { Compostela }\end{array}$ & $\begin{array}{l}\text { Lecturer. Research focused on regional } \\
\text { innovation policy. }\end{array}$ \\
\hline 2 & $\begin{array}{l}\text { University of Santiago de } \\
\text { Compostela }\end{array}$ & $\begin{array}{l}\text { Lecturer. Research focused on regional } \\
\text { development and regional } \\
\text { divergence/convergence. }\end{array}$ \\
\hline 3 & $\begin{array}{l}\text { University of Santiago de } \\
\text { Compostela }\end{array}$ & $\begin{array}{l}\text { PhD candidate, focused on innovation- } \\
\text { related public procurement. }\end{array}$ \\
\hline 4 & City of Madrid & $\begin{array}{l}\text { Responsible for European funds and } \\
\text { general coordination of administrative } \\
\text { action. Former deputy director of } \\
\text { innovation at the Ministry of Science and } \\
\text { Innovation in Spain. }\end{array}$ \\
\hline 5 & $\begin{array}{l}\text { Ministry of Economy, and } \\
\text { Competitiveness of Spain }\end{array}$ & $\begin{array}{l}\text { Deputy Directorate General for the } \\
\text { Promotion of Innovation. General } \\
\text { Secretariat for Science and Innovation. }\end{array}$ \\
\hline 6 & $\begin{array}{l}\text { Ministry of Economy, and } \\
\text { Competitiveness of Spain }\end{array}$ & $\begin{array}{l}\text { Deputy Directorate General for the } \\
\text { Promotion of Innovation. }\end{array}$ \\
\hline 7 & $\begin{array}{l}\text { Centre for the } \\
\text { Development of Industrial } \\
\text { Technology. Ministry of } \\
\text { Economy and } \\
\text { Competitiveness. }\end{array}$ & $\begin{array}{l}\text { Innovative Public Procurement } \\
\text { Coordinator. }\end{array}$ \\
\hline 8 & $\begin{array}{l}\text { Science and Innovation } \\
\text { Link Office. }\end{array}$ & $\begin{array}{l}\text { Director Public sector management. } \\
\text { Former Director of the Galician Innovation } \\
\text { Agency. }\end{array}$ \\
\hline 9 & $\begin{array}{l}\text { Galician Innovation } \\
\text { Agency. }\end{array}$ & Director of the innovation programs area. \\
\hline 10 & $\begin{array}{l}\text { Galician Innovation } \\
\text { Agency. }\end{array}$ & Director general. \\
\hline 11 & Galician Health Service. & $\begin{array}{l}\text { Healthcare IT and Digital Health Program } \\
\text { Manager. }\end{array}$ \\
\hline 12 & $\begin{array}{l}\text { Galician Health Knowledge } \\
\text { Agency. }\end{array}$ & Director general. \\
\hline 13 & $\begin{array}{l}\text { Galician Health Knowledge } \\
\text { Agency. }\end{array}$ & $\begin{array}{l}\text { Health Innovation and Development Area. } \\
\text { Coordinator of European Projects. }\end{array}$ \\
\hline 14 & $\begin{array}{l}\text { Galician Health Knowledge } \\
\text { Agency }\end{array}$ & $\begin{array}{l}\text { Former director of innovation programs at } \\
\text { the Galician Innovation Agency. }\end{array}$ \\
\hline
\end{tabular}

Source: own elaboration 